University of Nebraska - Lincoln

DigitalCommons@University of Nebraska - Lincoln

10-1969

\title{
Aspergillosis in Wintering Mallards
}

Gary Pearson

USGS Northern Prairie Wildlife Research Center

Follow this and additional works at: https://digitalcommons.unl.edu/usgsnpwrc

Part of the Other International and Area Studies Commons

Pearson, Gary, "Aspergillosis in Wintering Mallards" (1969). USGS Northern Prairie Wildlife Research Center. 88.

https://digitalcommons.unl.edu/usgsnpwrc/88

This Article is brought to you for free and open access by the US Geological Survey at DigitalCommons@University of Nebraska - Lincoln. It has been accepted for inclusion in USGS Northern Prairie Wildlife Research Center by an authorized administrator of DigitalCommons@University of Nebraska - Lincoln. 


\section{ASPERGILLOSIS IN WINTERING MALLARDS}

Losses among mallards (Anas platyrhynchos) wintering on a seepage ditch below the Garrison Dam on the Missouri River at Riverdale, North Dakota, were reported on February 24, 1968. In early February, while conducting their annual winter banding operation, personnel of the North Dakota Game and Fish Department observed approximately 1.000 mallards on the ditch. Approximately 200 mallards were banded after teing captured in a walk-in trap baited with corn and wheat located on the bank of the ditch. Snow covered the area and caused the ducks to concentrate at the bait site from the time of the banding operation until the reporting of the losses.

A total of 135 recently dead mallards (97 males, 38 females) were collected on February 24 and 25. An additional 42 mallard carcasses in various stages of decomposition were also found. There was evidence that predators had fed on some of the carcasses, and this prevented an accurate total count of the mortality. One sick drake mallard was captured on the 24th, but no affected birds were seen among an estimated 500 live ducks flushed from the trap site on the 25th. Subsequent searches failed to reveal further losses; this indicates that the major mortality may have been limited to a period of a few days. However, dispersion of the ducks during the moderate weather of the last few days of February may have been partially responsible for the apparent sudden cessation of losses.

Examination of 23 recently dead mallards revealed a general absence of subcutaneous and visceral fat and slight atrophy of the pectoral muscles. Fifteen males weighed an average of $1012 \mathrm{~g}$. and 8 females averaged $843 \mathrm{~g}$. Ecchymotic hemorrhages were present in the myccardium of many specimens. The lungs of all ducks examined were severely congested and contained multiple small (1-2 $\mathrm{mm})$, creamy-white, firm nodules. Interclavicular and anterior and posterior thoracic air sacs of most ducks were cloudy and thickened. In several cases the air sacs contained plaques up to 5 $\mathrm{mm}$ in diameter, and some exhibited definite mycelia. Occasionally, plaques were present on kidneys and other abdominal organs.

Histologically, sections of lung tissue which were stained with hematoxylin and eosin showed a generalized hemorrhagic pneumonia and lymphocyte infiltration. Numerous granulomas consisting primarily of epithelioid cells, lymphocytes and occasional foreign body giant cells were present; some showed evidence of necrosis at the centers. Branching fungal hyphae were observed in many of the air capillaries as well as in the granulomas, of lung sections stained by the periodic acid-Schiff technique. Hyphae also were evident, frequently without direct host reaction, in many of the air capillaries of the hematoxylin and eosin stained sections.

Blood agar plates were incculated with lung and air sac lesions from the sick drake which died shortly after capture and with air sac lesions of another fresh carcass. Aspergillus, typical of $A$. fumigatus, was isolated from each lesion. Cultures of heart blood, liver and contents of the small intestine of the sick drake did not reveal the presence of pathogenic bacteria.

Although a possible source of the infection appeared to have been corn used in baiting the trap site, no grain was present at the time losses were noted. However, examination of the corn supply which was used revealed extensive mold growth on many of the ears. A diet consisting solely of this corn failed to produce infection in penned mallards. This may have been a reflection of a different route of infection or the absence of factors which may have reduced resistance to infection (Herman and Sladen, 1958, Trans. N. Amer. Wildl. Conf. 23: 187-191). The relatively low number of banded ducks among those found dead and the incomplete information of the ducks' activities prior to the observed losses suggest that other possible sources of infection cannot be excluded. 
Epornitics of aspergillosis in free- geese (McDougle and Vaught, 1968, J. flying wild waterfowl have been reported Wildl. Mgmt., 32: 415-417). This outin mallards (Herman, 1943, Calif. Fish break appears to differ from the above \& Game, 29: 204, and Neff, 1955, J. in that a higher mortality (at least 13\%) Wildl. Mgmt., 19: 415-416), wood ducks occurred in the course of only a few (Bellrose, Hanson and Beamer, 1945, J. days.

Wildl. Mgmt., 9: 325-326), and Canada

\section{Acknowledgements}

The author is indebted to Charles Schroeder and George Enyeart of the North Dakota Game and Fish Department and to William McClure, U.S. Game Management Agent, for assistance in gathering specimens and information, and to Dr. Louis N. Locke of the Patuxent Wildlife Research Center for reviewing histological interpretations.

\section{GARY L. PEARSON}

Bureau of Sport Fisheries and Wildlife

Northern Prairie Wildlife Research Center

Jamestown, North Dakota 58401

August 21, 1969 